Original Research

\title{
Identifying Soils for Reduced Tillage and No-Till Farming Using GIS
}

\author{
Jozef Vilček ${ }^{1,2}$, Štefan Koco ${ }^{1,2}$, Stanislav Torma ${ }^{1}$, Tomáš Lošák ${ }^{3}$, Jacek Antonkiewicz ${ }^{4 *}$ \\ ${ }^{1}$ National Agricultural and Food Centre, Soil Science and Conservation Research Institute, Prešov, Slovak Republic \\ ${ }^{2}$ Department of Geography and Regional Development, Faculty of Humanities and Natural Sciences, \\ University of Prešov, Prešov, Slovak Republic \\ ${ }^{3}$ Department of Environmentalistics and Natural Resources, Faculty of Regional Development and International Studies, \\ Mendel University in Brno, Brno, Czech Republic \\ ${ }^{4}$ Department of Agricultural and Environmental Chemistry, Faculty of Agriculture and Economics, \\ University of Agriculture in Krakow, Krakow, Poland
}

Received: 8 March 2018

Accepted: 6 May 2018

\begin{abstract}
Reduced tillage and no-till farming technology is possible to employ only under particular soil conditions. The total land area of sites in Slovakia that are available for the application of reduced tillage is approximately $25.3 \%$ of agricultural land ( $20.4 \%$ very suitable and $4.9 \%$ less suitable), while $74.7 \%$ of soils are not suitable for this technological approach. Only $19.8 \%$ of soils $(17.8 \%$ very suitable and $2.0 \%$ less suitable) are suitable for no-till farming technologies of soil preparation before sowing, while $80.2 \%$ of soils are not suitable for this method. The best conditions for these approaches are found in soil types such as Chernozems, Cutanic Luvisols, Mollic Luvisols, and Fluvisols, but also Albic Luvisols and Regosols located on plains, in lowland areas, and in lower altitude basins. In the higher altitude regions, we do not recommend employing these technologies. The identification of areas suitable for this method is possible using the information in the databases of the Soil Science and Conservation Research Institute in Bratislava, which have been managed in this study using a geographic information system. The input parameters were the altitude of a given locality, as well as the slope steepness, depth, stoniness, and texture of the soil. It turns out that GIS is also an appropriate means for identifying and categorizing landscapes and agricultural lands in order to implement differentiated (reduction) cultivation systems.
\end{abstract}

Keywords: GIS, reduced tillage, no-till farming, soil categorisation

\section{Introduction}

As an alternative to traditional methods of agricultural soil tillage, reduced tillage allows for the

*e-mail: rrantonk@cyf-kr.edu.pl

reduction of certain commonly used tillage operations. Soil quality improvement by reducing soil tillage is one from the tools of sustainable agriculture [1]. Reduced soil tillage involves treatments that reduce the number of mechanical operations, including seeding, nutrition, and plant protection [2]. From an ecological point of view, this type of cultivation can preserve soil fertility in the long term and protect soil from degradation (soil 
erosion and carbon sequestration). These technologies are essentially simplified methods of soil cultivation in practice. The no-till farming method of pre-sowing soil preparation is an extreme method of reduced soil tillage, where no movement of soil is permitted except where necessary to allow for the incorporation of seeds. This system is applicable only to soils that provide optimal conditions for the germination of seeds and the development of the root system of plants, without previous cultivation intervention. Also, the soil conditions must be respected while implementing such procedures in practice; this is one of the determining limits for the application of soil preparation using a no-till farming system. The term "reduced-soil tillage" includes soil-protective technologies as well. These are characterised by more than $30 \%$ of the soil surface covered by the crop residues of the preceding crop and intercrop [3]. In addition to the ecological benefits, such as higher contents of oxidable carbon (Cox), total nitrogen $(\mathrm{Nt})$, and microbial carbon, these technologies enable better soil moisture management and offer economic benefits [4-6]. As the principal farm tool offering an effective and immediate solution toward positive changes in soil quality, productivity, and sustainability, zero tillage/conservation agriculture adoption needs financial incentives, which have high economic and environmental returns to society [7].

The success of reduced tillage and direct drilling depends on the crop species as well as on soil type and climatic conditions. Most important, using minimal soil tillage reduces the depth of soil processing. For shallower tillage, disk tools, stubble breakers, and soilscarifies are used, without subsequent deep tillage using a plough. This method, compared with the classical system of soil processing, is a less intensive operation and more cost-effective. A minimum tillage system saves 2.5 times more energy compared to the conventional tillage system. The economic analysis also revealed that the maximum benefits could be obtained from minimum tillage, following a system by raised bed and no tillage system and lowest in conventional tillage [8]. Almost all scientific work concerning this issue [9 and others] discuss the effects of such technologies on soil qualities or on crop yield. The effects of protection technologies on soil, its physical, chemical and biological parameters (conservation tillage impacts on soil) are analysed in Busari et al. [10], who stated that in fine-textured and poorly drained soils the use of minimum tillage is encouraged, while in well-drained soils with light to medium texture and low humus content the no-till systems seems to be advantageous. Zero or minimum tillage is beneficial to soil physical improvement as the process of soil physical degradation normally sets in immediately after conventional tillage, which causes higher bulk density and lower total porosity compared to no- and moderate-tillage systems [10]. On the other hand, there is almost no research available about types of soil (sites) that would be suitable for these purposes. For example, the delimitation of soil suitable for the cultivation of wheat by no-till farming technique using GIS in Pakistan [11] showed that zero tillage is being promoted on all kinds of soils in Pakistan - partly because no data is available, which delineate unsuitable soils from those that are suitable. The soils with silt clay loam or lighter soil texture, well drained and with no salinity, are best suited for zero-till wheat cultivation. Moderately suitable soils are clay/silty clay or silty clay loam and lighter with drainage problems. Finally, the unsuitable soils are saline and poorly drained with hard pan. Insufficient depth of the soil, high gravel content, intense gleisation, and podzolisation preclude the application of reduced tillage. McGarry et al. [12] stated that zero till is particularly attractive for clayey soils in order to minimise compaction and induce natural structure formation through shrink-swell cycles that increase soil water storage and increase numbers of (beneficial) soil fauna relative to traditional tillage.

Recent literature comparing conventional tillage with no-till methods in temperate agroecosystems with varying soil textures and climates has been reviewed for the purpose of assessing rates of change in the magnitude and stratigraphy of the bulk density, porosity, pore size classes, organic matter content, and organic matter fractions [13]. Conservation tillage methods in agriculture are commonly seen as effective measures to protect soil against erosion [14].

Processes of climate change mitigation and adaptation found zero tillage to be the most environmentally friendly among different tillage techniques. Therefore, conservation tillage involving zero tillage and minimum tillage, which has the potential to break the surface compact zone in soil with reduced soil disturbance, offers to lead to a better soil environment and crop yield with minimal impact on the environment [10]. Adoption of sustainable tillage can protect soils from biological degradation and maintain soil quality when compared with conventional management [15]. On the other hand, the no-tillage system increased the weed infestation of fields as compared to conventional cultivation (mouldboard ploughing) [16].

Reduced tillage and soil-protective technologies are suitable for soils with natural regenerative abilities of physical state and where water and wind erosion occurs [17]. Development of soil science information in recent years has made it possible to gain more specific data in this field. Our previous works [17, 18] were focused only on the potential application of minimized technologies in the separation according to agricultural production areas and administrative units (regions).

The aim of this paper was to identify the localities where it is possible to use not only reduced tillage but also technologies of no-till farming of soil based on knowledge of agricultural soil parameters in Slovakia using GIS. Although the choice of these technologies also takes into account other parameters (economic, technological, and ecological), these are not the subject of this study. Innovation of the results is not only in the categorization of areas suitable for such purposes, 
but also in specifying soil suitability according to type, climatic region, erosion threat, compaction, and production potential.

\section{Materials and Methods}

It is obvious that not every soil, outpost, or locality is suitable for the reduction of established agro-technical procedures and traditional soil tillage methods. Nowadays, due to modern geoinformatics technologies and existing databases about soils of Slovakia, we are able to locate, relatively accurately, the appropriate soils on which to apply such technologies, and also which soils are absolutely inappropriate for such actions. This has allowed us to perform a detailed soil survey of agricultural soils in Slovakia. This survey is the basis for determining the soil limits for this kind of management.

The categorisation of soils for the purposes of minimum soil tillage has used data deposited in databases in the Soil Science and Conservation Research Institute in Bratislava, Slovakia (SSCRI) regarding the properties of agricultural soils available as separate vector layers in digital form. The categorisation is based on aggregating (overlapping) these layers, according to the requirements of this soil tillage system on individual soil parameters. For reduced soil tillage, the following soil properties were analysed: soil texture, soil depth, slope, gravel content, and altitude.

For the categorisation of soils for the purpose of no-till farming, we used a database of soil properties covering the entire territory of Slovakia. Based on the results of field observation [2] and published literature [18 and other], we can say that in Slovakia the most suitable soils for reduced soil tillage technologies are deep soils, non or sporadic gravelly, sandy and loamy, located on planes or on slight slopes at altitudes leading up to $350 \mathrm{~m}$ a.s.1.
These parameters take into account the particularly crucial physical parameters of soils that predominantly predispose existing localities to reduced tillage and soil conservation cultivation. For the purposes of our research and this contribution, we have selected data on soil texture, stone content, the slopes of the soil, its depth, and the altitude. These data are available in vector format and are identifiable in the database of bonited soil ecological units of Slovakia. For these parameters, we selected threshold values of these limits (Fig. 1) so that they clearly specified the suitability of soils for these technologies. As there is no experimental research, the threshold values for soil limits has been chosen based on the realistic use of these technologies in practice (the practical experience of farmers) and the database specifications allowing for the categorization of the selected parameters, as well as our past knowledge of the relationship among soil properties, its production potential, and economic parameters [19].

Soil texture limits are based on the requirement of stable soil structure, water stock, and aeration (waterair regime). This requirement is most suitable for the loamy and sandy soils. Limits of slope steepness, stone content, and soil depth are related to production and economic potential. Production of crops is reduced by $18 \%$ on $3-7^{\circ}$ slopes compared with flatland (growing is still profitable). However, the reduction of production is by $36 \%$ less on slope over $7^{\circ}$ (profitability rate is negative: $-3 \%$ ). Higher loss of pesticides and their residues from the soil to water sources was taken into account in the case of slope steepness compared with conventional cultivation. Crop production is reduced by $34 \%$ on the soils with low stone content compared with soil without stones, and profitability rate decreased from 6.9 to $1.5 \%$. Production potential of medium-depth soils $(0.3-0.6 \mathrm{~m})$ is lower by $37 \%$ compared with very deep soils (more than $0.6 \mathrm{~m}$ ), and economic potential is at the limit of profitability. Altitude limits are related

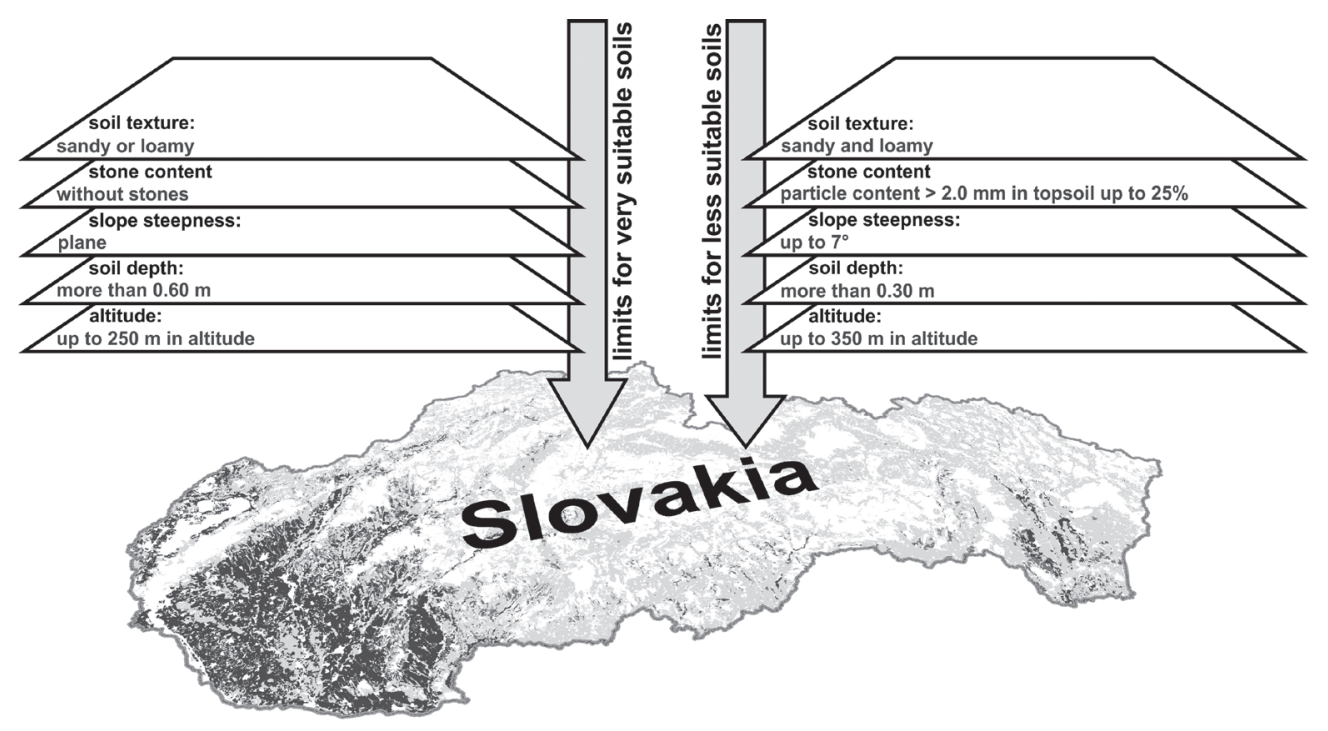

Fig. 1. Soil limits for the application of reduced-soil tillage technologies. 


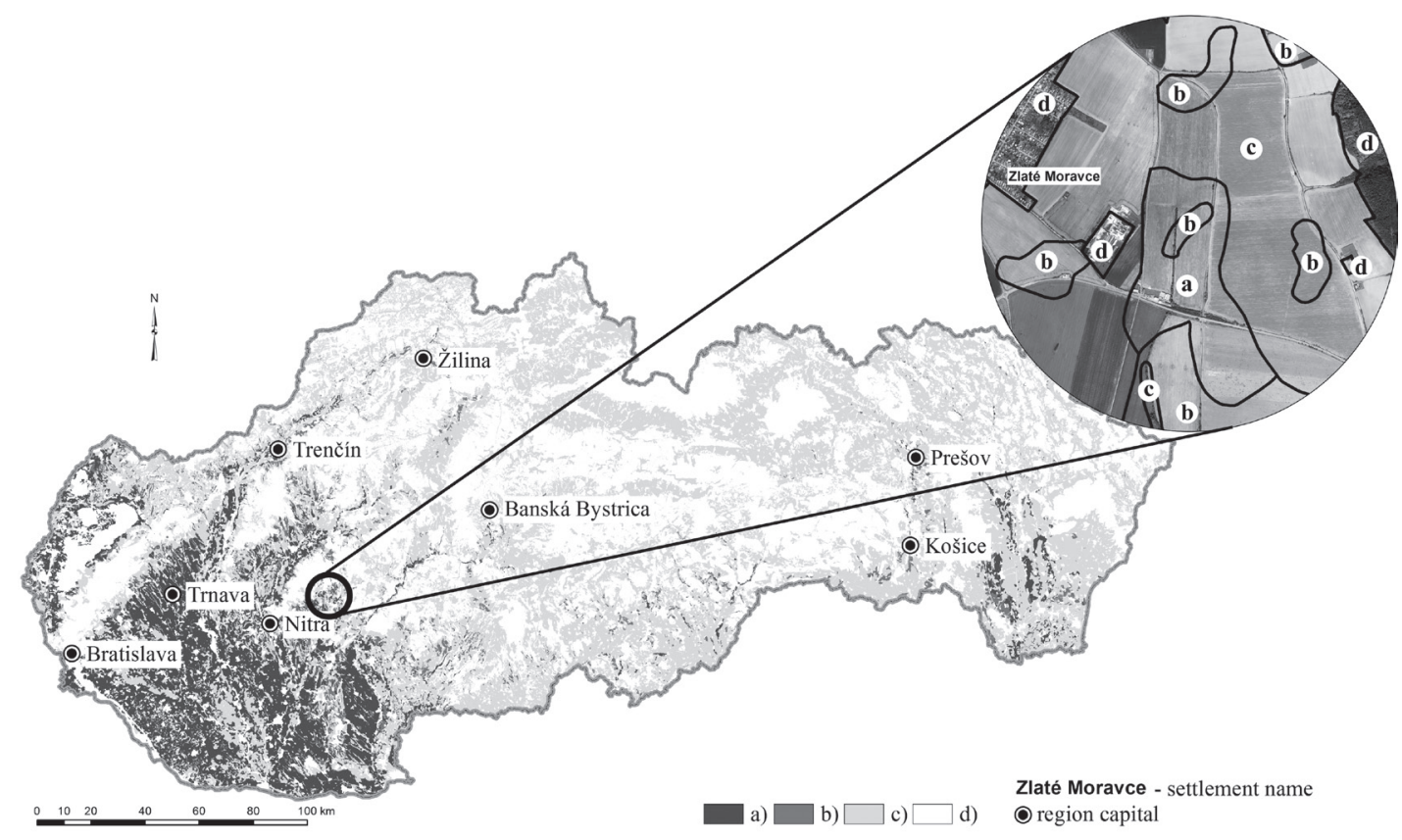

Fig. 2. Suitability of agricultural land in Slovakia for applying reduced-soil tillage agro-technical methods and its sample in hilly land area (in the background of the orthophotos): a) very suitable soils, b) less suitable soils, c) unsuitable soils, d) non-agricultural soils.

to the fact that protected cultivation of the soil reduces overheating of the topsoil, and this has a negative impact on the yields of some crops in colder and wetter areas. The germination of plants is delayed by 3-10 days, and further ontogenesis begins in a cooler microclimate.

Spatial identification and quantification of soils was performed according to these parameters on the basis of the data layer on soil parameters in Slovakia using a geographic information system, i.e., the ArcGIS environment. To identify the suitability of soils for reduced tillage agro-technical practices, a purposebuilt database of soil units was created using an overlay of layers identifying relevant parameters in the GIS environment. These units were then divided to three groups of suitability:

- Soils very suitable for minimal processing.

- Soils less suitable for minimal processing.

- Soils not suitable for minimal processing.

The soils that were not classified as very suitable or less suitable were identified as not unsuitable.

To identify the suitability of soils for no-till farming, the methodology of soil categorisation was applied, as in the case of reduced tillage technologies. However, sandy soils, sandy loam soils, and soils with a topsoil gravel content of more than $10 \%$ were excluded.

The following groups of suitability were formed:

- Soils very suitable for no-till farming technologies.

- Soils less suitable for no-till farming technologies.

- Soils not suitable for no-till farming technologies.

Additional limits include chemical and biological soil parameters, which can significantly influence the choice of the site as well. As these parameters are mostly timevariable and there is not a suitable spatial database on their occurrence, they were not considered in our method. The suitability of a particular site is limited by soil, climatic, agronomic, and anthropic parameters. It is worth mentioning the influence of the preceding crop, fertilisation, soil compaction, occurrence of weeds, site surface conditions, etc.

Unfortunately, we did not obtain enough useful information for their overall identification.

We used only existing databases about soils of Slovakia (SSCRI) that cover the whole Slovak territory, available as digital vector data models and therefore useful for GIS applications.

\section{Results and Discussion}

Identifying the soils suitable for reduced tillage and no-till farming technologies was processed by GIS and analytical overlapping of the layers (databases in the vector data format), describing the selected limited parameters of agricultural soils. The map created with this procedure reveals relatively large spatial heterogeneity in the spatial structure of suitable territories. The results show that $25.3 \%$ of soils in Slovakia are suitable for the application of reduced tillage technologies $(20.4 \%$ very suitable and $4.9 \%$ less suitable), while $74.7 \%$ of soils are unsuitable (Fig. 2).

By overlapping the suitability map of agricultural soils for applying reduced tillage agro-technical methods with databases and maps characterizing some other soil parameters (existing SSCRI soil databases about agroclimatic regions, soil types, erosion of soils and their potential compaction, point value of soils - see www. podnemapy.sk), we found out the following: 


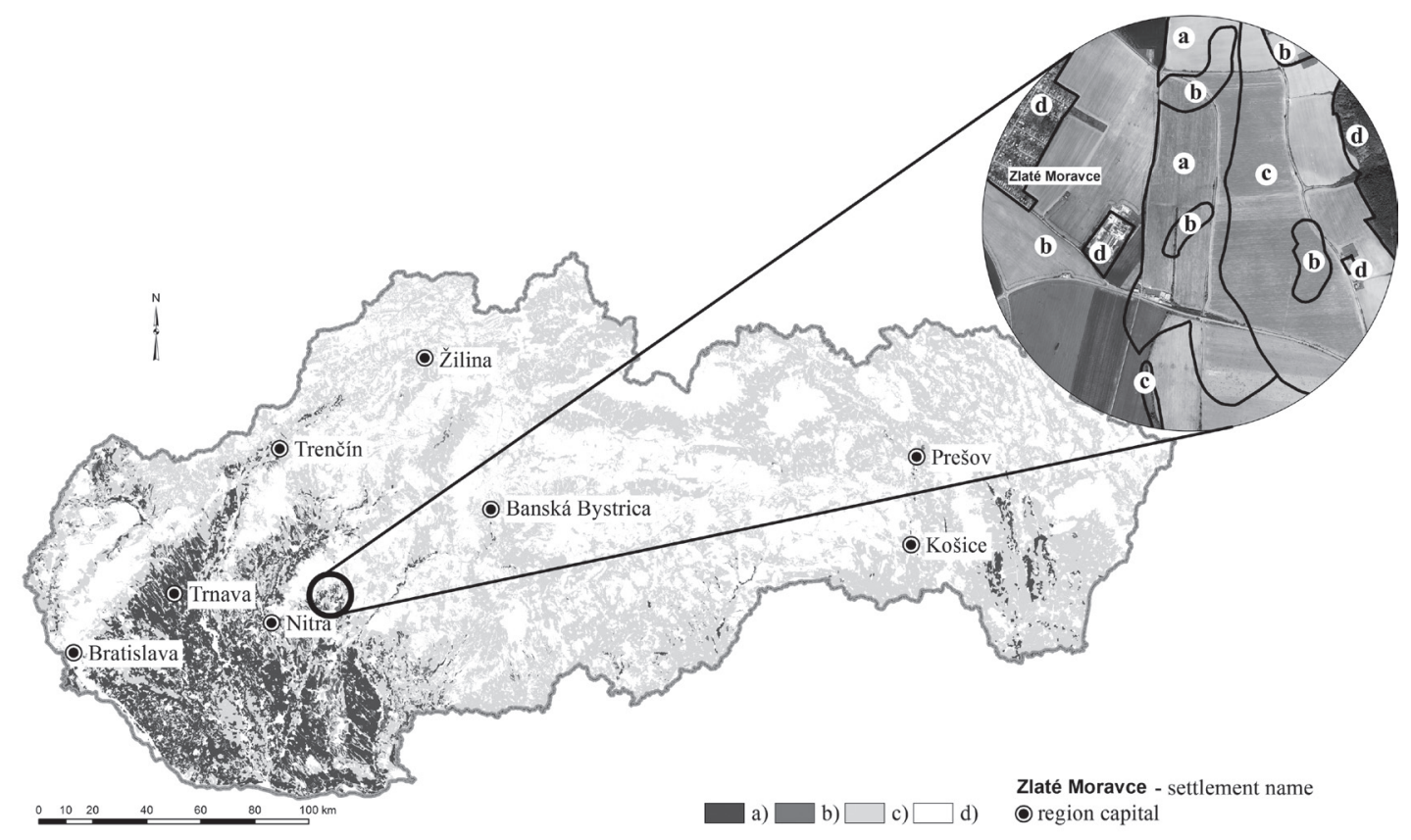

Fig. 3. Suitability of agricultural land in Slovakia applying no-till farming methods and its sample in the hilly land area (in the background of the orthophotos): a) very suitable soils, b) less suitable soils, c) unsuitable soils, d) non-agricultural soils.

- These areas are found in very warm, very dry, flat to warm, very dry, flat climatic regions [20].

- In the group of very suitable soils the predominant soil type [21] would be Chernozems $(47.6 \%$ of the whole of area of very suitable soils) and in the group of the less suitable soils, Cutanic Luvisols $(41.7 \%$ of the whole of area of less suitable soils) is the most common. Fluvisols (18.8, resp. 11.3\%) and Mollic Fluvisols (16.5, resp. 7.9\%) are less present and in the group of less suitable soils, Albic Luvisols, Cambisols, and Regosols are also present.

- While in areas with very suitable soils (plains) there is no water erosion, in less suitable areas $58.2 \%$ of soils is moderately (up to 10 t ha-1 year-1) endangered by water erosion.

- In both cases, approximately $23 \%$ of the areas are not endangered by compaction. However, up to $61.3 \%$ of the areas with very suitable soils are endangered by compaction in a secondary way (by human influence). It is only a $31.3 \%$ risk for the soils which are less suitable, but $33.6 \%$ of the areas is endangered by secondary as well as primary (genetic properties of soils).

- The group of very suitable soils is predominantly represented $(91.7 \%)$ by the most productive soils in Slovakia (with values of 70-100 points, while $47 \%$ represent soils with values of $80-90$ points). The group of less suitable soils is predominantly represented $(97.9 \%)$ by soils with point values greater than 50, while most areas (34.7\%) occupy soils with a point value of $70-80$ points.

Based on our research, we found that only $19.8 \%$ of soils (17.8\% very suitable and 2.0\% less suitable) in Slovakia are suitable for no-till farming methods of soil preparation before sowing, while $80.2 \%$ of soils are unsuitable (Fig. 3).

Regarding the no-till farming methods, the results would be as follows:

- These areas are found in very warm, very dry, flat to moderately warm, moderately moist climatic regions [20].

- The predominant soil type [21] in the group of very suitable soils is Chernozem $(52.2 \%)$ and Cutanic Luvisols (64.1\%) is the predominant soil type in the group of less suitable soils. Fluvisols (17.9 respectively 4.0\%) and Mollic Fluvisols (7.5 respectively $11,3 \%$ ) are also slightly present. Albic Luvisols $(1.8 \%)$ rarely occur in the group of less suitable soils.

- All soils in the very suitable group are not endangered by water erosion. On the other hand, $78.3 \%$ of less suitable soils are moderately threatened by water erosion (to $10 \mathrm{t} \mathrm{ha}^{-1}$ year $^{-1}$ ).

- Compaction does not endanger 12.0, respectively $13.9 \%$ of the areas; secondary compaction does not endanger 69.8 , respectively $61.2 \%$ of the areas; and primary compaction does not endanger 13.4, respectively $21.6 \%$ of the areas.

The group of very suitable soils is predominantly represented $(99.0 \%)$ by the most productive soils in Slovakia (point value 70-100 points, while 53.1\% represent soils with a value of $80-90$ points). The group of less suitable soils is predominantly represented $(98.0 \%)$ by soils with point values of more than 60 points, while most areas (66.5\%) occupy soils with point values of 70-80 points.

The spatial identification of soil suitability for reduced tillage and no-till farming methods shows that 
the best conditions for these approaches are in areas classified as lowlands and lower-altitude basins. In terms of the regional geomorphological divisions of Slovakia, the best areas for applying reduced tillage methods of soil processing are lowlands, hilly areas, and basins (Danubian flatlands, Danubian hills, Chvojnica hills, valley of the Vah River, upper Nitra basin, southern Slovak basin, Košice basin, and eastern Slovak flatlands). In higher altitude regions, we strictly do not recommend employing these technologies.

The current state of knowledge and soil property mapping, as well as the current technology of processing relevant soil-ecological knowledge, allows for the identification of suitable soils for reduced tillage. In this study, we obtained such information through the information service for Slovak soils overlaying the spatial results of our research (digital database in vector format) with an actual orthophoto map that allows for locating suitable soils for reduced tillage and no-till farming procedures on the individual plots level. Based on this information, a farmer can choose the appropriate method of soil processing.

\section{Conclusions}

Recently, reduced soil-protective tillage has become popular in Slovakia. These methods are often used in practice without knowing the suitability of the site and without incorporating the professional and practical experience of agriculturalists. In the Slovak Republic there is no official statistic (registry) about applying reduced tillage and no-till farming technologies. These technologies can be expanded to about 500,000 hectares ( $20 \%$ of agricultural land), which is estimated on the basis of past trends. In the present time these technologies are applied on lowland fertile soils.

The aim of this study was to provide information on soil suitability for all those interested in reducing tillage technologies.

Categorizing agricultural soils according to suitability for reduced tillage and no-till farming, based on general knowledge of soil suitability for minimal tillage, has been developed for conditions of Slovakia. Locations can be identified through the created information system (in GIS environment), using developed databases and map outputs to the level of a spatially homogeneous field (plots). Such a system allows (facilitates) decisions by farmers about utilizing agricultural technologies suitable for the local soil and ecological conditions. Good decisions then inevitably also bring economic benefits. It is good to know that not all plots are suitable for reduced tillage and no-till farming. In Slovakia, only 25.3\% of agricultural soils are suitable for these technologies.

\section{Acknowledgements}

This work was supported by the Slovak Research and Development Agency under contract No. APVV15-0406, and a Scientific Grant Agency of the Ministry of Education of the Slovak Republic and the Slovak Academy of Sciences under contract No. VEGA 1/0116/16.

\section{Conflict of Interest}

All authors declare no conflict of interest.

\section{References}

1. ARBOLEYA J., GILSANZ J.C., ALLIAUME F., LEONI C., FALERO M., GUERRA S. Minimum tillage and vegetable crop rotation. Agrociencia Uruguay, 16, 62, 2012.

2. KOVÁČ K., ANTAL J., LEHOCKÁ Z., MACÁK M., HORÁK J., NOZDROVICKÝ L., ŠPÁNIK F., VILČEK J., ŽÁK Š. Minimised and soil-protective technologies. (SPU Publishing: Nitra), 2010.

3. MACÁK M., LEHOCKÁ Z., ŽÁK Š., KOVÁČ K The effect of primary soil tillage and precipitation condition on soil bulk density. Lucrari Stiintifice, 40, 93, 2008.

4. SOBOCKÁ J., DODOK R., HRÍBIK J., FULAJTÁR E., TAKÁČ J., TARASOVIČOVÁ Z Suggestion of soil adaptation arrangements to moderate the effects of climate change. (VÚPOP Publisher: Bratislava), 2010.

5. AKBOLAT D., KUCUKALBAY M. Influence of Seed Bed Preparation Methods in Chickpea Cultivation on Soil Carbon Dioxide $\left(\mathrm{CO}_{2}\right)$ Emissions. Polish Journal of Environmental Studies, 23, 1101, 2014.

6. TRIPATHI R.S., RAJU R., THIMMAPPA K. Impact of Zero Tillage on Economics of Wheat Production in Haryana. Agricultural Economics Research Review, 26, 101, 2013.

7. LANDERS J.N., RASS G., DE FREITAS P.L., BASCH G., GONZÁLEZ SANCHEZ E.J., TABAGLIO V., KASSAN A., DERPSCH R., FRIEDRICH T., GIUPPONI L. Effects of Zero Tillage (No-Till) Conservation Agriculture on soil physical and biological properties and their contributions to sustainability. Geophysical Research Abstracts, 15, EGU General Assembly, 2013.

8. SHARMA P., ABROL V., SHARMA R.K. Impact of tillage and mulch management on economics, energy requirement and crop performance in maize-wheat rotation in rainfed subhumid inceptisols, India. European Journal of Agronomy, 34, 46-51. doi.org/10.1016/j. eja.2010.10.003, 2011.

9. MÜHLBACHOVÁ G., KUSÁ H., RŮŽEK P. Soil characteristics and crop yields under different tillage techniques. Plant Soil and Environment, 61, 566, 2015.

10. BUSARI M.A., KUKAL S.S., KAUR A., BHATT R., DULAZI A.A. Conservation tillage impact on soil, crop and the environment. International Soil and Water Conservation Research, 3, 119, doi.org/10.1016/j. iswer.2015.05.002, 2015. 
11. IQBAL F., MEHDI M.R. Detection of suitable soils for Zero-Till Wheat Cultivation in Pakistan using GITs. In Proceedings of International Workshop on Earth Observation and Remote Sensing Applications, 30 June - 2 July 2, Beijing. doi: 10.1109/EORSA.2008.4620300, 2008.

12. MCGARRY D., BRIDGE B.J., RADFORD B.J. Contrasting soil physical properties after zero and traditional tillage of an alluvial soil in the semi-arid subtropics. Soil and Tillage Research, 53, 105, doi. org/10.1016/S0167-1987(99)00091-4, 2000.

13. KAY B.D., VANDENBYGAART A.J. Conservation tillage and depth stratification of porosity and soil organic matter. Soil and Tillage Research, 66, 107, doi.org/10.1016/ S0167-1987(02)00019-3, 2002.

14. HÖSL R, STRAUSS P. Conservation tillage in the alpine forelands of Austria - Are they effective? Catena, 137, 44, doi.org/10.1016/j.catena.2015.08.009, 2016.

15. JANUŠAUSKAITE D., KADŽIENĖ G., AUŠKALNIENĖ O. The Effect of Tillage System on Soil Microbiota in Relation to Soil Structure. Polish Journal of Environmental Studies, 22, 1387, 2013.
16. BŁAŻEWICZ-WOŹNIAK M., PATKOWSKA E., KONOPIŃSKI M., WACH D. Effect of cover crops and ploughless tillage on weed infestation of field after winter before pre-sowing tillage. Romanian Agricultural Research, 33, 185, 2016.

17. VILČEK J., KOVÁČ K. Sites availability for minimalizing and soil-conservation tillage of soils in Slovakia. Agriculture (Pol'nohospodárstvo), 57, 68, 2011.

18. VILČEK J., LISNYAK A. Ecological features of the potential of soils for minimalizing and soi-conservation tillage in Slovakia. Bulletin of V.N. Karazin Kharkiv National University, 1054, 103, 2013.

19. VILČEK J., ZVERKOVÁ, M. Pedogeography. (PU Publishing: Presov), 2015.

20. DŽATKO M. Agro-climatic regions of Slovakia. (VCPÚÚPVR Publishing: Bratislava), 1989.

21. WRB World Reference Base for Soil Resources: a Framework for International Classification, Correlation and Communication. (FAO Publishing: Rome), 2006. 
